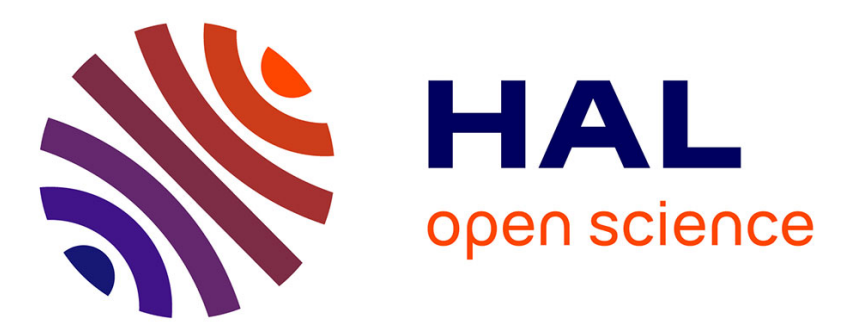

\title{
Digital Development: Elements of a Critical ICT4D Theory and Praxis
}

\author{
Anna Bon, Hans Akkermans
}

\section{To cite this version:}

Anna Bon, Hans Akkermans. Digital Development: Elements of a Critical ICT4D Theory and Praxis. 15th International Conference on Social Implications of Computers in Developing Countries (ICT4D), May 2019, Dar es Salaam, Tanzania. pp.26-38, 10.1007/978-3-030-19115-3_3 . hal-02281305

\section{HAL Id: hal-02281305 https://hal.inria.fr/hal-02281305}

Submitted on 9 Sep 2019

HAL is a multi-disciplinary open access archive for the deposit and dissemination of scientific research documents, whether they are published or not. The documents may come from teaching and research institutions in France or abroad, or from public or private research centers.
L'archive ouverte pluridisciplinaire HAL, est destinée au dépôt et à la diffusion de documents scientifiques de niveau recherche, publiés ou non, émanant des établissements d'enseignement et de recherche français ou étrangers, des laboratoires publics ou privés. 


\title{
Digital Development: Elements of a Critical ICT4D Theory and Praxis
}

\author{
Anna Bon ${ }^{1}$ and Hans Akkermans ${ }^{2}$ \\ ${ }^{1}$ CIS, International Office, Vrije Universiteit Amsterdam, The Netherlands \\ ${ }^{2}$ Network Institute, VU Amsterdam, and AKMC, The Netherlands \\ a.bon@vu.nl, Hans.Akkermanseakmc.nl
}

\begin{abstract}
In recent years, critical research literature in ICT4D has grown. It is widely accepted that theory is to inform practice. However, the inverse directionality, practice informs theory, is much less present in ICT4D, including in critical research. In this paper, we discuss ways how ICT4D research and theory may be better informed by practice --- in terms of (i) recognizing praxis-oriented research paradigms and integrating their results, (ii) development of foundational theories, (iii) critical analysis of ICT4D emerging policies, and (iv) positioning ICT4D in the wider development debate. This suggests several elements or directions in which critical research has the potential to push current boundaries of ICT4D in terms of content as well as relevance.
\end{abstract}

Keywords: Principles for Digital Development, Critical Research, Action Research Paradigm, Network Complexity Theory.

\section{Introduction: Critical ICT4D Research}

Recent years have seen a growing stream of critical ICT4D research. It is broadly compatible with suggested guiding 'Principles for Critical Research in Information Systems' (IS), as proposed in [1], and applied to ICT4D in [2]. The first principle formulated is: 'The principle of using core concepts from critical social theorists'.

Recent ICT4D research references a variety of critical social theorists, including Habermas [3], Bourdieu [4,5], Freire and Sen [6], Escobar and Spivak [7], other postcolonial theory [2], and Foucault, who is a key reference point for many postcolonial authors themselves (e.g., Escobar [8]). The general pattern in this literature can be characterized as: (i) selecting a specific critical perspective (in particular, a critical theory author); and (ii) applying this to ICT4D empirical case studies so as to provide a critical interpretation of an ICT4D practice case - usually with a local focus.

In view of recent discussions of the future ICT4D research agenda, calling for a stronger inter/transdisciplinary approach and for increased relevance and impact $[9,10]$, and in view of the above-noted apparent one-perspective and one-directionality of theory to practice in current literature, this paper suggests some directions for critical research to push the boundaries of the ICT4D state of the art.

In particular, we discuss ways how ICT4D research and theory may learn from and be better informed by practice -- in terms of (i) recognizing praxis-oriented research paradigms and integrating their results (Sec. 2); (ii) development of foundational the- 
ories (Sec. 3); (iii) critical analysis of emerging ICT4D policies (Sec. 4); and (iv) positioning of ICT4D within the wider development debate (Sec. 5).

\section{Praxis: The Action Research Paradigm and its Principles}

Experiential knowledge, including from the South. A first element suggesting a direction to strengthen critical ICT4D research consists in forging a stronger exchange between theory and practice. It is widely accepted (even taken for granted) that theory is to inform practice. The inverse directionality, practice informs theory, is however much less present in ICT4D research.

Admittedly, many insights from ICT4D practice are not available in the easy format of (rigorous, peer-reviewed) scholarly publications as ICT4D theoretical work is. If practitioners publish at all, their work is rather considered as contributing specific case studies (i.e., having no or limited bearing on general scientific theory), or as 'popular' (i.e., non-scientific) contributions such as one finds in the wide-ranging, relevant and interesting (also for scientists) ICT4D practitioners blog ICTworks [11].

It would be severely limiting, however, for ICT4D research to ignore or play down such sources of knowledge. For example, whereas in theory of ICT4D discourse the contextuality of IS and ICT4D systems is often stressed in abstracto, in accounts of practice one finds ample examples of real-world contexts in concreto and, moreover and highly importantly, how one can actually deal with such contextuality on-theground. Moreover, much practical knowledge is action-oriented, experiential and often tacit in nature (phronetic, to use Aristotle's terminology), as is indigenous knowledge relevant to big societal domains (e.g. agriculture, medicine) where ICT4D purports to make a difference. In general, as forcefully argued by Boaventura de Sousa Santos [12], the Global North may learn a lot from epistemologies of the South (see also [13-20]). We submit that this also definitely applies to ICT4D and IS.

Action Research as a Distinct ICT4D Research Paradigm. A step forward would be to recognize that there is a broader range of research paradigms that are valuable in IS and ICT4D, where to date positivist, interpretivist/constructionist, and critical research paradigms have met with 'official' scientific recognition, witness [21,22,1].

However, this does not at all exhaust the range of research paradigms that are valuable. In particular, there has been already for a long time a small but steady stream of action research [23]. In ICT4D, published action research comprises, a.o., long-standing work from Oslo in Health Information Systems in several countries [24], in South Africa in a variety of domains [25-27], and from Amsterdam related to rural development (regreening [14]) in the Sahel [28,29]. Action research represents a family of approaches, but in development (the D of ICT4D) it has a clear genealogy dating back to the work of (critical social theorists in their own right as) Fals Borda [30], Freire [31], and Chambers [32].

Participatory action research in IS and ICT4D constitutes a different and separate research paradigm, as it has underlying guiding principles that are significantly different from those of positivist [21], interpretive [22], and critical [1] research, as concisely shown in Table 1 . The various points made there can easily be illustrated by the referenced action research literature in ICT4D in this paper as well that outside this 
domain. Comparing action research with the guiding principles of critical research [1], similarities (Principles 1, 2, 6) as well as differences (Principles 3, 4, 5) are noted.

Table 1. Guiding principles of the action research paradigm (Source: authors).

\begin{tabular}{|r|l|}
\hline \multicolumn{1}{|l|}{ No. } & Principle \\
\hline 1 & Principle of Critical Investigation of Concrete Situations (field, professional practice) \\
\hline 2 & $\begin{array}{l}\text { Principle of Value: Developing/Taking a Value Position (democracy, emancipation, au- } \\
\text { tonomy, social and economic betterment) }\end{array}$ \\
\hline 3 & $\begin{array}{l}\text { Principle of stakeholder Collaboration (involving Co-Investigation, Co-Design, Co- } \\
\text { Creation, whereby goals and interests as seen by stakeholders themselves are central) }\end{array}$ \\
\hline 4 & Principle of Dialogue (between multiple actors and stakeholders (to be) involved) \\
\hline 5 & Principle of Action: Discovery and subsequent Realizing Change for the Better \\
\hline 6 & Principle of Reflection and continuous Learning in Action \\
\hline
\end{tabular}

\section{$3 \quad$ Foundational Theory: Network Complexity in Sociotechnical Innovation}

ICT4D Action = Sociotechnical Innovation. ICT4D research has an important role in doing critical groundwork leading to a better theoretical understanding of the many real-world phenomena and their interactions that together are constitutive of the field of ICT4D and Digital Development. Learning from practice delivers new insights also for general theory. A key starting consideration that we put forward here is that any ICT4D action and any form of Digital Development -- even if it employs established, so-called `non-advanced' ICT technology (e.g., radio, GSM mobile) -- unavoidably entails fundamental and strongly interlinked processes of sociotechnical innovation.

Overseeing the research (as for example cited above) that has a long-term connection with practice on the ground, one finds a general and acute awareness of this key point. A recurring theme is that change is not a linear and direct effect caused by introduction of new technology, which can be measured and evaluated in terms of predetermined goals, (ideally) by means of straightforward pre/post randomized controlled trial quasi-experiments (as simple-minded policies but also positivist science would like to have it, even today).

Instead, basic research needs to theorize the deeply intertwined social (overlapping local and global, communal and policy/political) aspects as well as technical aspects. This involves ICT/IS design and engineering, but also the associated specific ICT technologies affordances and the subsequent much broader struggles over the pathways of innovation that are to lead to betterment of people's lives and livelihoods.

Network Complexity Theory. Related reflective work in ICT4D action research repeatedly (and independently) points to `nonlinear' (sociotechnical) network complexity theory as a fruitful foundational theory. For example, Braa et al. [33,34] invoke complexity theory to achieve a better understanding of the 'networks of action' involved in health IS in developing countries. As another example, Bon [29] employs network complexity theory and discusses smallholder and family farmer innovation in 
the Sahel [14] and the roles of ICTs in scaling communication and knowledge sharing between smallholder farmers both as a Complex Adaptive System (CAS).

It is worth noting that complexity theory is proposed as a fruitful foundational theory also elsewhere in the field of development, and moreover by authors that are very differently positioned in the critical social theory debates. Ramalingam [35] offers, based on complexity theory, a book-length critique of the still predominantly linear thinking in development circles. Chambers, in recent work, e.g. [36], regularly refers to complexity theory, in the setting of sustainable livelihood analysis in an extended sense (also nonlocal, and 'bringing politics back in') as recently discussed by Scoones [37], and long ago already by Bernstein et al. [38]. Postdevelopment author Escobar refers to complexity theory at length in his very recent work [19], especially in relation to the struggles of indigenous and Afro-descendant peoples in Colombia and other Latin-American countries. Struggles, we note, that are actively supported by academic researchers through various forms of action research (here, Fals Borda's influence is clearly visible), called 'collective research and action' (investigación y acción colectiva (IAC)).

Finally, the name of Rogers, through his famous Diffusion of Innovations Model (DIM), has for a long time been associated with the linear technology transfer and diffusion models that were (and still are) en vogue also in development policies. Historically this is not unjustified (as reflectively acknowledged by Rogers himself in later editions of his DIM book), but it does not do proper justice to the later DIM theory. In fact, in a (posthumously published) article Rogers et al. [39] discuss the DIM model in the light of Complex Adaptive Systems theory, and reach the conclusion that DIM and CAS can be very well brought into a co-theoretical model, with a pivotal conceptual role for heterogeneous and differentiated social networks and the associated 'strength of weak ties'.

Complexity vs. ANT. It is interesting to ponder why so many different authors with significant participation in practice independently come to refer to complexity theories as a useful framework. One may flesh this out also by comparing it to features of another theory that has gained some traction in recent ICT4D and IS theory [9]: actornetwork theory (ANT). What is appealing across the board is the notion of mixed, heterogeneous social and technical networks. For ICT this is even more obvious as it is a network technology itself, but evidently it is not limited to such cases. We note that taking as central the network viewpoint is an important conceptual step. Namely, it implies that individuals are not in the first place taken as entities (object classes in UML or database terms) with (locally held/owned) identifiable individual properties or attributes, or privately holding utility functions as in mainstream economic market theories. Instead, already in formal-mathematical network theory, an individual or node is (in the limiting case) simply the nexus of its relations (links, ties) to other nodes. Thus, network theory implies an inherently relational ontological view on the human species and also on its technologies, a point elaborated by Escobar in [19].

Directly relevant to ICT4D, there is, by the way, an interesting (and even explicit) link here with early groundbreaking work from computer science -- in particular at the intersection of Artificial Intelligence (AI), knowledge engineering and systems (KE/ $\mathrm{KBS}$ ), and Human-Computer Interaction (HCI) -- regarding systems Design Thinking [40]. Given current trends in ICT4D donor programs to launch cutting-edge Digital 
Development initiatives concerned with the latest ICT technology advances ('Big Data' 4D, 'IoT' 4D, `Blockchain' 4D, 'Drones' 4D, `AI' 4D, etc.), renewed reading of Winograd and Flores's (1986) seminal work would be insightful also for today's ICT4D and IS research.

Where complexity theory and ANT depart is foremost in two specific assumptions made by ANT (see also the discussion by Walsham, $c f$. [9]). In a sort of putting postmodernism (that celebrates the notion of 'difference' as against essentialism and 'totalizing') on its head, it ontologically erases all differences between agents, human actors and technologies, and moves everything into a flat world of 'actants'. This sounds indeed extremely 'radical' and potentially theoretically innovative. But, for many it begs the question what interesting analytical progress can be made as a result of such an assumption. In ICT4D and IS many (practitioners as well as researchers) would tend to say that paying careful attention to differences is actually key to doing justice to the diversity of contexts in which systems have to function to benefit. Secondly, ANT has strongly the flavour of a purely microscopic theory. It does not want to allow in or recognize pre-existing larger structures (e.g., of power or other field-like social theories). Rather, it expresses the ambition to generate them dynamically (when it is said that power is the variable to be explained). But to date it has not been very successful here, as it lacks a clear proposal what the generating mechanisms are. It is worthwhile to quote here a critical comment (referring to postmodernism, constructionism, poststructuralism) by Mbembe, a postcolonial author 'writing Africa':

"On the pretext of avoiding single-factor explanations of domination, these disciplines have reduced the complex phenomena of the state and power to 'discourses' and 'representations', forgetting that discourses and representations have materiality" ([41], p. 7).

Complexity theory does in our view a much better job here. It does not have a problem to recognize that there are initial conditions that represent the pre-existence of power and other structures and, unlike ANT, it does propose ways to generate macroscopic structure from what appears to be randomness or even chaos at the microscopic level. It is precisely the interaction between (local) microscopic behaviour and (global) macroscopic structural features that can trigger specific forms of emergence and self-organized structures (something completely overlooked by ANT). This is very visible especially in the many bio-ecological models of complexity, but it is already present in the early (1960's) complexity theories in physics and chemistry (cooperative 'synergetic' phenomena in lasers (Stuttgart, Haken et al.) and emergent macroscopic structure in chemical reactions ('order out of chaos', Brussels, Prigogine et al.)). Very recently, like-minded Web Science research has emerged concerning the digital sphere, thus directly relevant to ICT4D and IS, such as on the World Wide Web as a complex adaptive system [42].

Thus, network complexity theory appears to much better than ANT correspond to the everyday realities (including structures and power residing in-between as well as emanating from various aboves) as felt on the ground by 'the poor' and 'the unconnected', and also as experienced by practitioners and researchers in the field. 


\section{$4 \quad$ Policy and Practice: The 9 Principles for Digital Development}

Implementation Principles. If ICT4D research would like to escape the harsh verdict by Harris [10] that much of it lacks relevance and fails the poor, there is a pressing need to address policy issues as to what the '4D' in ICT4D is supposed to mean. Also here academic research may be informed by and learn more from practice.

As a specific recent policy relevant to ICT4D, we refer to the emergence of the notion of 'Digital Development' [43,44] and the associated so-called 9 Principles for Digital Development [45]. Importantly, there is an evident aspiration here to acquire some sort of canonical (normalized, naturalized) or even hegemonial status with respect to defining and implementing ICT4D-related policies --witness the explicit push by especially USAID for development organizations to officially express and even sign formal adherence to these principles.

This should be all the more reason for ICT4D research and its hoped-for relevance to critically analyze such tendencies. Whether the orientation is toward academic scholarship, real-world research, practice, or policy, ICT4D has no choice but to reflectively position itself in such debates [46].

Key Principles for Digital Development are formulated as "Be Collaborative", "Design With The User", "Understand the Existing Ecosystem", “'Build for Sustainability" [45]. They are presented (by USAID) as new and as a radical break with conventional development policy. Abstracting from ICT technologies, one is reminded of earlier periods (1980/90's) where conventional development policies were intellectually and politically challenged in different ways [32,47], studies to hear the bottom-up voices of the poor were commissioned, and grassroots livelihood approaches entered the scene at the policy level. Collaborative work, putting the poor, the marginalized, the unconnected at the centre, were then, and are now, undoubtedly highly desirable Principles, also for Digital Development and ICT4D.

Statements of principle as indicated above obviously express good intentions. Good intentions alone, however, do not yet settle the matter. What ultimately matters is how they are translated into meaningful action on the ground. Current ICT4D academic literature is not of much help here. It has a tendency to relegate ICT4D practice on the ground to matters of 'implementation' ([48], Ch. 3; [49], Ch. 11), mistakenly suggesting that practitioner issues are of a derivative nature and/or relatively straightforward. Academic ICT4D research has a tendency to stay at the level of principles; even critical research does not get beyond high-level statements of principle such as that ICT4D implementation 'can often be done most effectively in a series of carefully moderated workshops at the start of any intervention' ([49], p. 364). It is then quite surprising that even in self-described critical literature one finds support ([50], p.1061) for the Base-of-the-Pyramid strategy [51] where already a superficial reading makes clear that western capitalist profit motives, rather than the interests of the poor, are at the centre. In contrast, the ICT4D practitioner community itself has pointed out that principles alone are not enough: there are significant obstacles to putting the good intentions of the Principles for Digital Development into real practice [52], adding that some obstacles reside in conventional development policy itself. 
The General Gap Between Developers and Users. If one takes the Principles for Digital Development as a starting point, a primary ICT4D question that comes up is: how can one come to know what 'the unconnected' actually want, need or have an interest in, such that this can be turned into a basis for building valuable information systems? Even adopting a collaborative user-centered philosophy, this primary ICT4D question is highly non-trivial. An important general difficulty across ICT is the gap between technology developers and end-users, the supposed beneficiaries of new technologies. Already in the Global North, in western (advanced) contexts, this gap has a proverbial status both in IS engineering research and in the software industry: 'users never know what they want'. In Global South contexts this gap is evidently even bigger, witness a community radio program maker interviewing our ICT4D team in rural Mali (Radio Moutian, Tominian, Mali, 16 January 2011): “First tell me what the World Wide Web is, my listeners have never heard of it."

Under such conditions, answers and solutions to the above primary ICT4D question are not pre-determined, but can only emerge on the ground from a dialogical IS design and lifecycle development process. Here, however, state-of-the-art academic ICT4D/IS research has as yet not succeeded in providing concrete handles for such collaborative and dialogical processes in the field. In our work $(e . g .,[28,29])$ we have therefore endeavoured to bridge this gap between theory and practice, by providing practical ICT4D methodologies that work and have been tested in a way useful to ICT4D practitioners and students new to the field.

As pointed out by Sahay et al. [53], explaining why ICT4D is a big challenge, mainstream IS research is typically focused on (Global North) managerial and business concerns regarding ICT in organizations. (M)IS research is best viewed as social studies of information systems (with commonly a business school bias). Just as writing about architecture is different from doing it, being an observer of IS phenomena is notably different from being actually involved in Information Systems design and engineering (as IS and ICT4D practitioners are). Thus, mainstream IS research covers only a part of the whole IS field (albeit that its self-image seems to be different).

Here, we touch upon a point also made by Walsham [9]: ICT4D and IS research need to take up a more interdisciplinary outlook. There are outside bodies of knowledge that offer significant contributions as to how one may construct answers to the above-mentioned primary ICT4D question in collaborative and dialogical practice ways. IS engineering literature (with commonly a bias toward informatics and computing sciences: 'techne', including requirements and software engineering) has quite something to offer, but this goes largely unnoticed in much IS and ICT4D research as a result of monodisciplinary bias. In particular, state-of-the-art concepts, theories and methodologies from so-called agile engineering can be adapted and extended to work in challenging and demanding development contexts, throughout the full IS lifecycle (as elaborated by Bon et al. [28,29], see also references therein).

IS Engineering Bodies of Knowledge. This should not in fact come as a surprise. As pointed out above, the gap between ICT/IS developers and users/customers is a significant problem in western 'advanced' contexts already for a long time. Systems engineering in the Global North has also been dominated by linear models (known as the waterfall model) of ICT/IS technology transfer and software project management for most of the 20th century. The many resulting big IS project failures (so, ICT4D is cer- 
tainly not alone here) triggered the development of alternative models. Accordingly, the linear waterfall model in IS and software has gone into decline, and agile engineering has emerged around the turn of the century as an explicitly iterative, adaptive and collaborative alternative. Today, one may even say that agile IS engineering has become the de facto industry standard in the West, especially for those ICT and software industries that have their customers in non-ICT industries, government and societal organizations. Apparently, this fact has not yet fully established itself in the mainstream IS and ICT4D research and policy consciousness.

So, perhaps there are also some epistemologies of the North that may be useful to the Global South. State-of-the-art technical engineering IS bodies of knowledge provide, or can be adapted to provide, many practical solutions to implementing collaborative Principles of Digital Development (which is not to say that these Principles themselves shouldn't be critically investigated) [29].

In addition, along these lines one also finds some more concrete ICT4D answers as to the question of the often-claimed contextuality of IS. This is a scholarly issue that cannot be decided upon in abstracto. Instead, it has to be substantiated by extensive field research and co-operative inquiry on the ground in development contexts, i.e., from critical praxis. Judging from evaluations of the authors' own ICT4D courses students, contextuality, rather than functioning as an IS theoretical concept, is first of all to be experienced.

From our own action-research empirical and theoretical work we can offer some hopefully useful observations here. In ICT4D and also in Digital Development policy, ICT is often first of all conceptualized in terms of infrastructure and devices (access to internet, Web, social media, Internet of Things, etc.). We believe this is the wrong way to go. If one talks about, say, rural development in the West-African Sahel, one is not in the first place talking about ICT, but about possibilities for betterment of livelihoods by people --- and ICTs may have some (but maybe none) role. Thus, contextuality of IS means in the first place thinking from and about the (extended) livelihoods of people $[37,38,14]$. Accordingly, in on-the-ground ICT4D field research work, there will be an emphasis on the early stages, because they are the hardest, and they happen to be the ones where ICT technologies themselves play yet no role or only in the background.

\section{$5 \quad$ ICT4D 3.0: The Missing 10th Principle for Digital Development -- "Putting the Last First"}

A Critique of Development as Interventionism. In analyzing the Principles for Digital Development and their value, one has to cut deeper. Collaboration is an important value, or Principle, but just on itself it can also be employed in exploitative, profitcentered or harmful co-optation ways in a neoliberal 'flattening of the world' [54]. In discussing the implementation of the Principles for Digital Development, the ICT4D practitioner community itself has noticed [52] that there are obstacles in still dominant Global North-led conventional development policy.

The key point that we want to put forward here is that development has been framed for decades in terms of 'intervention'. The term intervention is widely, loosely, but unreflectively used in development circles (in policy, practice as well as research 
(such as in [55]). In Foucauldian terms, it has become a normalized and naturalized concept. But it is not at all a normal or natural concept, it is a fundamental framing concept that needs to be unpacked. 'Intervention' evidently has strong connotations of medical curation, laboratory experimentation, and exercise of political and military power. These all have deep implications for thinking about development and how it is becoming biased. Intervention, therefore, is not at all an innocent concept.

Intervention thinking (even if well-intentioned) runs counter to working in a truly Southern-led collaborative partnership way. (The Taiwan ICT4D critical case study presented in [2] could very well be re-interpreted as an example of intervention thinking and action, as outlined above). The problem is that such a policy unavoidably tends to lose sight of the lifeworld, livelihood, own goals and interests of supposed beneficiaries (in our case, smallholder farmers in the Sahel). Practice projects often (have to) provide 'donor satisfaction' instead of user/customer/beneficiary satisfaction. Thus, in our view, intervention thinking presents several current policy obstacles that are in the way of collaborativeness and putting the user in the centre:

i. The rather directive ways how big funds are programmatically spent (e.g., spread internet, with access posited as the key issue, often set in a neoliberal market frame, see the US and UK digital development content frameworks $[43,44]$;

ii. The imposed operational framework for project and program management (linear waterfall model, logframe, see for example the USAID ADS Chapter 200 implementation rules [56]);

iii. An associated hegemonic discourse whereby intervention from the outside is framed [57] as the 'natural' way of bringing about desirable change.

This critique applies to development in general, ergo, also to ICT in development.

ICT4D 2.0 Derailed? ' Like railways and roads before it, the ongoing digital revolution is unleashing waves of innovation." (www.usaid.gov/digital-development/digis/ 2018). The 9 Principles for Digital Development pointed at above are process-oriented principles. They are principles intended to govern implementation of policy. They do not state the content of this policy itself. The above quote does. Was ICT4D 1.0 the policy whereby the roll-out of telecentres was thought to be the key to ICT4D development, the above quote shows that ICT4D 2.0 [58] in its appearance of Digital Development first and foremost is the roll-out of network digital infrastructure, including internet, Web, and Web 2.0, social media, as is also apparent from the very recent digital policy documents $[43,44]$.

What is striking is that ICT4D and the new 'Digital Development' is foremost conceptualized content-wise as the rolling out of current Western ICT infrastructure of connectivity to the Global South. Then, Digital Development is not at all a radical break with previous conventional development policy, it is a continuation of it. The metaphor of railways and roads used by USAID itself is an appropriate one. It reminds one of western movies and what happened to native peoples in the US in the 19th century, and it positions the roll-out of internet and Web as a next phase of infrastructural intervention. The benefits of this are rather simply proclaimed in general terms (see the continuation of the above USAID quote at the indicated website). Moreover, it is carefully avoided to consider the 'powers that be' that are the dominant commercial market forces behind the current internet and Web infrastructures, even if 
this is a very contested issue these days also in the Global North. Again, in ICT4D 2.0 as in ICT4D 1.0, the supposed beneficiaries, the poor and unconnected, are not really asked for their opinion as it comes to the content and priorities of the new ICT4D policy of Digital Development. This is why ICT4D 3.0 is needed: a 10th goal-oriented Principle is missing in Digital Development: Putting The Last First.

"Decolonizing Theory, Practicing Solidarity" [20]. We have discussed ways how ICT4D research and theory may be better informed by practice, in terms of (i) recognizing praxis-oriented research paradigms such as participatory action research and integrating their results, (ii) development of foundational theories, (iii) critical analysis of ICT4D emerging policies such as Digital Development, and (iv) positioning ICT4D in the wider development debate. A case has been made for ICT4D 3.0 as an approach that is collaborative throughout all phases of the IS lifecycle, and that includes collaborativeness not just in the development implementation process, but also in agenda setting and goal construction and associated decision making. Strengthening Southern-driven cooperation thus requires turning away from intervention thinking and putting Southern goals and interests central in research and IS design from the very beginning. And there exist practical ICT4D methodologies for doing so [28,29].

\section{References}

1. Myers, M.D., Klein, H.K.: A Set of Principles for Conducting Critical Research in Information Systems. MIS Quarterly 35(1), 17-36 (2011)

2. Lin, C.I.C., Kuo, F.-Y., Myers, M.D.: Extending ICT4D Studies: The Value of Critical Research. MIS Quarterly 39(3), 697-712 (2015)

3. Unwin, T.: Reclaiming Information and Communication Technologies for Development. Oxford University Press, Oxford, UK (2017)

4. Singh, H., et al.: The Practice of ICT-enabled Development. Information Technology for Development 24(1), 37-62 (2018)

5. Krauss, K.E.M.: Practice-driven Theory: Using Bourdieu's Critical Lineage in ICT4D Work. In: Steyn, J., Van der Vyver, A.G. (eds.): Public and Private Access to ICTs in Developing Regions, pp. 126-151. Proceedings 7th International Development Informatics Association Conference, Bangkok, Thailand (2013). ISBN: 978-0-620-58040-3

6. Poveda, S., Roberts, T.: Critical Agency and Development: Applying Freire and Sen to ICT4D in Zambia and Brasil. Information Technology for Development 24(1), 119-137 (2018)

7. De', R., et al.: ICT4D Research: A Call for a Strong Critical Approach. Information Technology for Development 24(1), 63-94 (2018)

8. Escobar, A.: Discourse and Power in Development: Michel Foucault and the Relevance of his Work to the Third World. Alternatives 10(3), 377-400 (1984)

9. Walsham, G.: ICT4D Research: Reflections on History and Future Agenda. Information Technology for Development 23(1), 18-41 (2017)

10. Harris, R.: How ICT4D Research Fails The Poor. Information Technology for Development 22(1), 177-192 (2016)

11. ICTworks blog and website, www.ictworks.org. Last accessed 02 Feb 2019

12. Santos, B. de Sousa: The End Of The Cognitive Empire: The Coming Of Age of Epistemolo- gies Of The South. Duke University Press, Durham, NC, USA (2018) 
13. Mbembe, A.: Critique Of Black Reason. Duke University Press, Durham, NC, USA (2017)

14. Reij, C., Waters-Bayer, A. (eds.): Farmer Innovation In Africa. Earthscan Publications, Lon- don, UK (2001)

15. Tuhiwai Smith, L.: Decolonizing Methodologies - Research and Indigenous Peoples. ZedBooks, London, UK, 2nd Ed. (2012)

16. Denzin, N.K., Lincoln, Y.S., Tuhiwai Smith, L.: Handbook of Critical and Indigenous Methodologies. SAGE Publications, Thousand Oaks, CA, USA (2008)

17. Kovach, M.: Indigenous Methodologies - Characteristics, Conversations, and Contexts. University of Toronto Press, Toronto, Canada (2009)

18. Santos, B. de Sousa: Epistemologies of the South - Justice Against Epistemicide. Rout- ledge, Abingdon, Oxon, UK (2014)

19. Escobar, A.: Designs For The Pluriverse - Radical Interdependence, Autonomy, and The Making Of Worlds. Duke University Press, Durham, NC, USA (2018)

20. Mohanty, C.T.: Feminism Without Borders: Decolonizing Theory, Practicing Solidarity. Duke University Press, Durham, NC, USA (2003)

21. Guba, E. G., Lincoln, Y. S.: Competing Paradigms in Qualitative Research. In Denzin, N.K., Lincoln, Y.S. (eds.): Handbook of Qualitative Research, pp. 105-117. SAGE, Thousand Oaks, CA, USA (1994)

22. Klein, H.K., Myers, M.D.: A Set of Principles for Conducting and Evaluating Interpretive Field Studies in Information Systems. MIS Quarterly 23(1), 67-94 (1999)

23. Bradbury, H. (ed.): The SAGE Handbook of Action Research, 3rd. Ed., SAGE, London, UK (2015)

24. Braa, J., Sahay, S.: Health Information Systems Programme: Participatory Design within the HISP Network. In Simonsen, J., Robertson, T. (eds.): Routledge International Handbook of Participatory Design, Ch. 10, pp. 235-256. Routledge, Abingdon, Oxon, UK (2013)

25. Buskens, I., Earl, S.: Research for Change: Outcome Mapping's Contribution to Emancipatory Action Research in Africa. Action Research 6(2), 171-192 (2008). https://doi.org/10.1177/1476750307087051

26. Buskens, I.: Online Social Networks and Global Women's Empowerment. Communications of the ACM 60(4), 22-23 (2017). https://doi.org/10.1145/3055275

27. Herselman, M., Botha, A.: Designing and Implementing an Information Communication Technology for Rural Education Development (ICT4RED). CSIR Meraka, Pretoria, South Africa (2014). ISBN 978-0-7988-5618-8

28. Bon, A., Akkermans, H., Gordijn, J.: Developing ICT services in a Low-Resource Development Context. Complex Systems Informatics and Modeling Quarterly 9, 84-109 (2016). https://doi.org/10.7250/csimq.2016-9.05

29. Bon, A.: Intervention or Collaboration? Rethinking Information and Communication Technologies for Development. Pangea, Amsterdam, The Netherlands (2019). ISBN 978-9078289-11-1 (e-book: see https://w4ra.org/publications)

30. Fals Borda, O.: Investigating Reality In Order To Transform It: The Colombian Experience. Dialectical Anthropology 4, 33-55 (1979)

31. Freire, P.: Pedagogy of the Oppressed. Continuum, New York, NY, USA (2005, 30th Anniversary Edition; original edition in English 1970)

32. Chambers, R.: Rural Development: Putting The Last First. Routledge, Abingdon, Oxon, UK (1983, reprint 2013)

33. Braa, J., Monteiro, E., Sahay, S.: Networks of Action: Sustainable Health Information Systems Across Developing Countries. MIS Quarterly 28(3), 337-362 (2004). 
34. Braa, J., et al.: Health Information Systems in Indonesia: Understanding and Addressing Complexity. In: Choudrie, J., et al. (eds.): Proceedings ICT4D 2017, IFIP AICT 504, pp. 59-70, Springer International Publishing, Cham, Switzerland (2017). https://doi.org/ 10.1007/978-3-319-59111-7_6

35. Ramalingam, B.: Aid On The Edge Of Chaos. Oxford University Press, Oxford, UK (2013)

36. Chambers, R.: Inclusive Rigour For Complexity. Journal of Development Effectiveness 7(3), 327-335 (2015). https://doi.org/10.1080/19439342.2015.1068356

37. Scoones, I.: Sustainable Livelihoods and Rural Development. Practical Action Publishing, Bourton on Dunsmore, Rugby, Warwickshire, UK (2015)

38. Bernstein, H., Crow, B., Johnson, H. (eds.): Rural Livelihoods - Crises and Responses. The Open University, Oxford University Press, Oxford, UK (1992)

39. Rogers, E., et al.: Complex Adaptive Systems and the Diffusion of Innovations. The Innova- tion Journal 10(3), article 3, pp. 1-25 (2005)

40. Winograd, T., Flores, F.: Understanding Computers and Cognition - A New Foundation for Design. Addison-Wesley, Reading, MA, USA (1986)

41. Mbembe, A.: On The Postcolony. University of California Press, Berkeley, CA, USA (2001)

42. O’Hara, K., Contractor, N.S., Hall, W., Hendler, J.A., Shadbolt, N.: Web Science: Understanding the Emergence of Macro-Level Features on the World Wide Web. Foundations and Trends in Web Science 4(2-3) 103-267 (2012)

43. USAID resource website on Digital Development, www.usaid.gov/digital-development. Last accessed 02Feb 2019

44. DFID: Digital Strategy 2018 to 2020: Doing Development in a Digital World. UK policy paper available from: www.gov.uk/publications (2018)

45. Principles for Digital Development, https://digitalprinciples.org. Last accessed 02 Feb 2019

46. Mohanty, S.P.: Us and Them: On the Philosophical Bases of Political Criticism. Yale Journal of Criticism 2(2), 1-31 (1989)

47. Escobar, A.: Encountering Development: The Making and Unmaking of the Third World. Princeton University Press, Princeton, NJ, USA (1995, expanded edition 2012).

48. Heeks, R: Information and Communication Technologies for Development (ICT4D). Routledge, Abingdon, Oxon, UK (2018)

49. Unwin, T. (ed.): ICT4D. Cambridge University Press, Cambridge, UK (2009)

50. Kleine, D., Unwin, T.: Technological Revolution, Evolution and New Dependencies: what's new about ICT4D? Third World Quarterly 30(5), 1045-1067 (2009)

51. Prahalad, C.K., Hammond, A.: Serving the World's Poor, Profitably. Harvard Business Review 80(9), 48-57 (2002)

52. Waugaman, A.: From Principle to Practice: Implementing the Principles for Digital Develop- ment. The Principles for Digital Development Working Group, Washington, DC, USA (2016). Available from digitalprinciples.org

53. Sahay, S., Sein, M.K., Urquhart, C.: Flipping the Context: ICT4D, the Next Grand Challenge for IS Research and Practice. Journal of the Association for Information Systems 18(12), 837-847 (2017)

54. Harvey, D.: Cosmopolitanism And The Geographies Of Freedom. Columbia University Press, New York, NY, USA (2009)

55. Pandey, V., Gupta, S.: A Comprehensive Four-Stage Framework for Evaluation of ICT4D Interventions. Information Technology for Development 24(3), 511-531 (2018) 
56. USAID: ADS Chapter 200 Operations Policy documents, www.usaid.gov/who-weare/agency-policy/series-200. Last accessed 02 Feb 2019

57. Schön, D.A., Rein, M.: Frame Reflection - Toward the Resolution of Intractable Policy Controversies. Basic Books, New York, NY, USA (1994)

58. Heeks, R.: ICT4D 2.0: The Next Phase of Applying ICT for International Development. Computer 41(6), 26-33 (2008) 